\title{
A novel approach for the removal of lead (II) ion from wastewater using Kaolinite/Smectite natural composite adsorbent
}

\author{
I. M. El-Naggar ${ }^{1} \cdot$ Sayed A. Ahmed ${ }^{2} \cdot$ Nabila Shehata $^{3} \cdot$ E. S. Sheneshen ${ }^{4} \cdot$ Mahmoud Fathy $^{5} \cdot$ Amr Shehata $^{5}$
}

Received: 7 May 2018 / Accepted: 3 October 2018 / Published online: 12 December 2018

(C) The Author(s) 2018

\begin{abstract}
Lead is one of the fundamentally risky metal ions existing in wastewater. A laboratory batch technique carried out to study the impact of initial concentration, $\mathrm{pH}$, temperature, a dose of adsorbent and contact time on the elimination of lead ions onto oil shell sedimentary rock as natural clay. Two natural inorganic composites Kaolinite/Smectite-A and Kaolinite/ Smectite-B have been used. The lead removal enlarged with rising initial metal solution concentration, contact time and $\mathrm{pH}$. The elimination reaction speed was high at the initial period of contact time and then decreased to attain equilibrium at 45, 30 min for Kaolinite/Smectite-A and Kaolinite/Smectite-B adsorbents, respectively. Mutually, Langmuir and Freundlich's isotherms are applicable to describe the metals adsorption and thermodynamic parameters $\Delta G ; \Delta S$ and $\Delta H$ were calculated indicating that the adsorption process is physisorption, spur-of-the-moment and endothermic.
\end{abstract}

Keywords Heavy toxic element $\cdot$ Natural adsorbent $\cdot$ Waste $\cdot$ Lead $\cdot$ Removal $\cdot$ Adsorption

\section{Introduction}

Environmental pollution became one of the common important subjects that attract the attention of many scientists at the present time (Fathy et al. 2016a). Toxic metals have a dangerous impact on human health, and these substances may go into human body either directly in drinking water

Mahmoud Fathy

Fathy8753@Yahoo.com

I. M. El-Naggar

Eman.Sheneshen85@gmail.com

Sayed A. Ahmed

skader_70@yahoo.com

Nabila Shehata

nabila@psas.bsu.edu.eg

E. S. Sheneshen

Eman.Sheneshen@Yahoo.com

1 Hot Labs Centre, Atomic Energy Authority, Cairo 13759, Egypt

2 Faculty of Science, Beni Suef University, Beni Suef, Egypt

3 Faculty of the Postgraduates Studies for Advanced Sciences, Beni Suef, Egypt

4 Egyptian Ministry of Environment, Cairo, Egypt

5 Egyptian Petroleum Research Institute, Cairo, Egypt or indirectly via food, plant, fish, and meat. The discharge of great amounts of unsafe metals into the natural environment has caused a number of environmental troubles and due to their non-biodegradability and persistence, can collect in the environmental elements such as food chain, and thus may cause a major risk to human health. Hazardous metals include toxic heavy metal as a byproduct of various industries such as lead, copper, cadmium, and radionuclides as a byproduct nuclear facilities (i.e., nuclear power plants, fuel reprocessing plants, and nuclear research centers) such as cobalt and cesium and others (El-Maghrabi et al. 2017).

Kaolinite and smectite are found as a common constituent of soils and sediments. When different types of pollutants in domestic sewage, industrial effluents, sludge and other solid wastes are dumped on the earth surface, the soil particles including Kaolinite and smectite minerals can interact with the pollutants. The Kaolinite and smectite minerals in soil may therefore play a role in scavenging pollutants from the environment. Kaolinite and smectite have a low CEC of the order of 3-20 meq/100 g, and therefore it is not expected to be an ion exchanger of high order. Thus, Kaolinite and smectite mineral can be a potential adsorbent owing to its low cost, rich natural abundance, and high mechanical and chemical stability. Consequently, Kaolinite and smectite mineral should exhibit significant potential for use in the adsorption and separation of heavy metals. Yet few studies 
have investigated the suitability of acid-treated clay minerals for heavy metals capture or their adsorption mechanism. The small number of exchange sites is located on the surface of kaolinite and it has no interlayer exchange site. Nevertheless, the small CEC and the adsorption properties may play an effective role in scavenging inorganic and organic pollutants from water. Lead can damage central nervous system and reproductive system, kidney, liver, basic cellular processes and brain functions. It causes many toxic symptoms such as anemia, insomnia, headache, dizziness, irritability, weakness of muscles hallucination and renal damages (Fathy et al. 2016b). Different tools can be used for the management of wastewater. The removal of these metals from industrial wastewaters has recently become more profound with increasing industrial activities. There are many highfrequency techniques which can be used to remove heavy metal ions as chemical precipitation, ion exchange, evaporation and solvent extraction. Reverse osmosis, ultra-filtration, and micro-filtration process are considered as less frequently used methods. A mixture of diverse methods may be applied to improve the overall decontamination factor, but the best one is ion exchange technique because it is simple and can be regenerated to get back the metal ions again to benefit from them in various fields. This study depends on clay as natural materials because they are environmentally friendly as well as cheap and available in order to achieve the principle of sustainable development and reduce the emissions that cause the phenomenon of climate change threatening life on the planet (Farrag et al. 2016a). Clays were classified according to their crystal structure and the amount and locations of electric charge (deficit or excess) per unit cell into crystalline clays range from kaolin, which are relatively uniform in chemical composition, to smectite, which vary in their composition, cation exchange properties, and ability to expand. Kaolin is composing of alumino-silicates in nature arranged in an open box crystal structure which is occupied by cations and water molecules. Ionic exchange and reversible rehydration happened between these ions and water molecules in large cavities (Farrag et al. 2016b).

Finally, this research aims to determine lead adsorption behavior from aqueous solution onto two natural composite materials Kaolinite/Smectite-A and Kaolinite/Smectite-B as natural clay was taken from oil shell sedimentary rock.

\section{Experimental methods}

\section{Chemicals, reagents, and instrumentations}

In all experiments, deionized water was used for analytical purposes and for washing of clay from Egypt. All chemicals, materials obtained from BDH (England) and Loba Chemie (India) and used without further purification. The instruments used in this study are visible (UV visible spectrophotometer, XRD, FTIR, balance, shaker and PH meter that commonly used in laboratories.

\section{Preparation of clay}

The clay obtained from Wasif and Bayda, Egypt was treated by contacting $50 \mathrm{~g}$ of clay with $500 \mathrm{~mL}$ of $\mathrm{H}_{2} \mathrm{O}_{2}$ and then, $0.1 \mathrm{M} \mathrm{HCl}$ for $2 \mathrm{~h}$ to remove organic material and metal ions salts, respectively. Finally, the treated clay was washed with an excess of hot deionized water, decanted, and sundried. The samples were then pulverized and passed through mesh sieves of sizes $500-800 \mu \mathrm{m}$ to obtain acid modified clay (Fathy et al. 2015a). The two types are then treated with caustic soda $20 \%$ weight/weight at $400{ }^{\circ} \mathrm{C}$ for $2 \mathrm{~h}$. The outside rock is washed with distilled water and then treated by sulfuric acid again $20 \%$ volume/volume for $2 \mathrm{~h}$ at $40{ }^{\circ} \mathrm{C}$, Then dried in the oven for $24 \mathrm{~h}$ and left to cool afterward for use in treatment.

\section{Characterization of clay}

The infrared spectroscopy of modified samples was obtained by using a Fourier transform infrared (FT-IR) spectrometer (Fourier-380FT-IR, America). The crystallinity of the clay was determined by powder X-ray diffraction (X' Pert Pro MPD, Holland) with filtered $\mathrm{Cu} \mathrm{K} \alpha$ radiation operated at $40 \mathrm{kV}$ and $40 \mathrm{~mA}$. Solid morphology and average crystal size were determined by scanning electron microscopy (SEM) (Philips-FEI XL30 ESEM-TMP, Holland).

\section{The general procedure of adsorption}

A binary stock solution of $1000 \mathrm{mg} / \mathrm{L}$ containing $\mathrm{Pb}^{2+}$ ions was prepared by dissolving a known amount of its respective salt in $1 \mathrm{~L}$ of deionized water. From the stock solution, different concentrations from 125 to $500 \mathrm{mg} / \mathrm{L}$ were prepared. The $\mathrm{pH}$ of the solution was adjusted between 1.0 and 5.0 using $\mathrm{pH}$ meter instrument, $0.1 \mathrm{M} \mathrm{NaOH}$ or $0.1 \mathrm{M}$ $\mathrm{HCl}$ was added dropwise if required. The adsorption experiments carried out in $100 \mathrm{~mL}$ Erlenmeyer flasks by adding $1 \mathrm{~g}$ adsorbent clay to $50 \mathrm{~mL}$ of the aqueous metal ion solution. The mixture was shaking at the certain agitation speed (250 rpm) for 15-120 min (Farrag et al. 2016a). The temperature change was between 30 and $75^{\circ} \mathrm{C}$. Then, the content was centrifuged and absorbance was recorded by using a UV-visible spectrophotometer.

The capacities of Kaolinite/Smectite-A and Kaolinite/ Smectite-B samples were determined by batch experiment technique. $1 \mathrm{~g}$ of the solid material was equilibrated with $50 \mathrm{~mL}$ of ionic strength about $0.1\left(\mathrm{~Pb}^{2+}\right)$ chloride solution with $\mathrm{V} / \mathrm{m}$ ratio equal $50 \mathrm{~mL} / \mathrm{g}$ for Kaolinite/Smectite$\mathrm{A}$ and Kaolinite/Smectite-B composites samples. Shaker 
thermostat was used at $30 \pm 1{ }^{\circ} \mathrm{C}$. After overnight standing the solid was separated and metal ion concentration was measured instrumentally (UV-visible spectrophotometer). The capacity value was calculated by the following formula;

Capacity $=\%$ uptake $/ 100 \times C_{0} \times \mathrm{V} / \mathrm{m} \times Z \quad(\mathrm{meq} / \mathrm{g})$

where $C_{0}$ is the initial concentration of the ions in solution, $V$ is the solution volume, $m$ is the sorbent mass and $Z$ is the valence of the exchanged ions.

\section{Chemical stability}

The chemical stability for two composite Kaolinite/Smectite-A and Kaolinite/Smectite-B was studied in water, acid $\left(\mathrm{HNO}_{3}\right.$ and $\left.\mathrm{HCl}\right)$ at different concentrations $[0.5,1,2,3$, 4, 5, 6 and $7 \mathrm{M}$ ] and base ( $\mathrm{KOH}$ and $\mathrm{NaOH})$ at different concentrations [0.1 M and $1 \mathrm{M}$ ], by mixing $100 \mathrm{mg}$ of each composites Kaolinite/Smectite-A and Kaolinite/Smectite-B and $100 \mathrm{~mL}$ of the desired solution with intermittent shaking for about 1 week at $30 \pm 1{ }^{\circ} \mathrm{C}$ (Fathy et al. 2014a).

\section{PH titration}

The $\mathrm{pH}$ titration method for the two composite Kaolinite/ Smectite-A and Kaolinite/Smectite-B carried out as follow; $(0.3 \mathrm{~g})$ of them placed in a column fitted with glass wool at its bottom. A glass bottle containing $50 \mathrm{~mL}$ of $0.001 \mathrm{M} \mathrm{HCl}$ placed below the column, and for determination of $\mathrm{pH}$, a glass electrode placed in the solution, then $100 \mathrm{~mL}$ of $0.01 \mathrm{M}(\mathrm{LiOH}, \mathrm{NaOH}$, and $\mathrm{KOH})$ poured into the column (Fathy et al. 2015b). Titration carried out by passing the alkali metal hydroxide at a drop rate of about $10 \mathrm{drops} / \mathrm{min}$ and continued to a $\mathrm{pH}$ of about $\approx 10$.

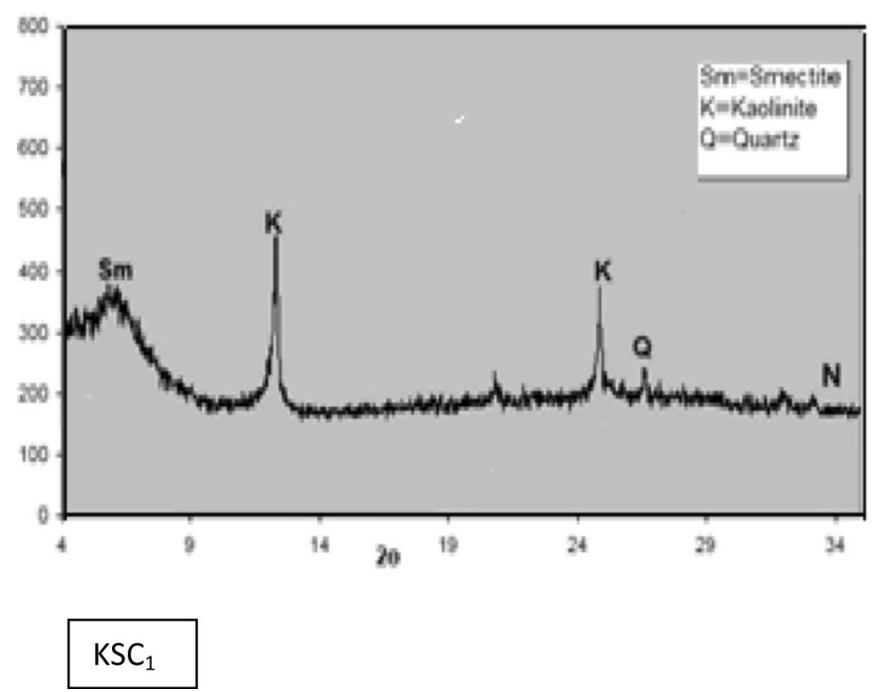

\section{Results and discussion}

\section{Characterization of the clay sample}

\section{XRD analysis of oil shell}

Two samples were examined using XRD instrument; results are shown below. From examination, the XRD pattern of two composites Kaolinite/Smectite-A (49.48/50.52) and Kaolinite/Smectite-B (22.48/77.52) kaolinite/smectite, respectively, from Wasif and Bayda, Egypt shows that it is a very small crystal that's mainly X-ray amorphous. Some minerals could be identified with more or less certainty (Fig. 1): quartz $\mathrm{SiO} 27.61-62.76 \%$, calcite 85.26-26.09\%, Gypsum $3.35 \%$, apatite $2.71 \%$ and some trace elements as seen in following two Tables 1 and 2. A kaolinite smectite yield X-ray diffraction pattern characterized by basal reflections that vary with minerals composition. The minerals were exposed to certain organic molecules, heat treatment, and exchangeable cations (Fernandez-Álvarez et al. 2010).

Composite XRD pattern represents a completely crystalline material. Figure 1 for smectite and kaolin composites shows clear reflections at the value of $2 \theta$ ranges between 12 and 25 which characteristics for kaolinite and another reflection around 5 characteristics for smectite.

\section{FTIR analysis}

It is important to determine the characteristic surface groups of Kaolinite/Smectite-A and Kaolinite/Smectite-B that are responsible for the adsorption of metal ions. Non-Fourier

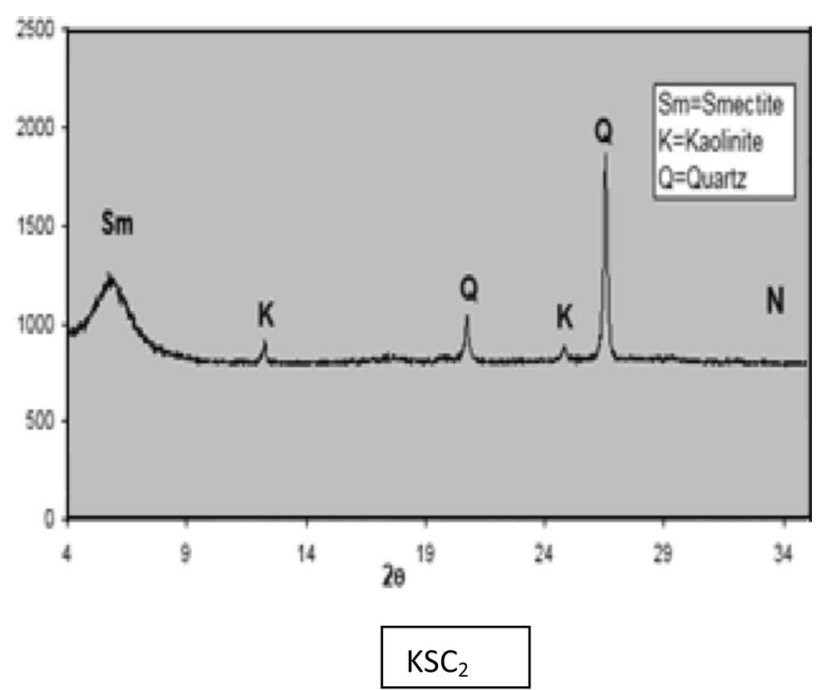

Fig. 1 XRD spectrum of oil shell Kaolinite/Smectite-A and Kaolinite/Smectite-B 
spectroscopy (FTIR) analysis was used to determine the functional groups. When Kaolinite/Smectite-A and Kaolinite/Smectite-B were saturated with $\mathrm{Pb}^{2+}$ cations, the colors and shapes of the IR bands (Fig. 2). The FTIR spectrum of Kaolinite/Smectite-A and Kaolinite/Smectite-B was used to obtain the data for the functional group elongation and flexion vibrations. The $\mathrm{Si}-\mathrm{O}$ elongation vibration of the smectite is seen around $1045 \mathrm{~cm}^{-1}$. The $\mathrm{Si}-\mathrm{O}$ stretch vibration of the smectite can be affected in the mineral adsorbed water. Water molecules were partially expelled by the measurement units as indicated by weak water bands in the sense of $1645 \mathrm{~cm}^{-1}$ (for example, Fig. 2), and $3400 \mathrm{~cm}^{-1}$ (spectra not shown). The living environment is a self-stretching band. However, several authors found that when content decreased in saturation assemblers with $+\mathrm{Na}^{+}$, the band of $1045 \mathrm{~cm}^{-1}$ became weaker. As the $1.044 \mathrm{~cm}^{-1}$ bands of the Kaolinite/ Smectite-A and Kaolinite/Smectite-B composites studied here were improved, but not weakened (Karime et al. 2008).

The FTIR spectra of two composite adsorbents Kaolinite/ Smectite-A and Kaolinite/Smectite-B are shown in Fig. 2. The FTIR spectral analysis of kaolinite smectite composite powder shows a distinct peak at 713.66, 875.68, 1419.61, $2515.18,2912.5$ and $3410.15(1 / \mathrm{cm})$. The peak is observed at $3410.15(1 / \mathrm{cm})$ due to the presence of alcoholic hydroxyl group $(-\mathrm{OH})$ stretching. This result suggests that $\mathrm{Pb}^{2+}$ interacts with metal oxides and $-\mathrm{OH}$ functional group presented in the kaolinite/smectite composite powder.

\section{SEM micrographs and observations}

SEM micrographs of two composite adsorbents Kaolinite/ Smectite-A and Kaolinite/Smectite-B are represented in Fig. 3. SEM micrographs of clay composites present homogeneous surfaces in the form of plates. This flocculated fabrics typical of highly swelling soils with high salt concentrations which reduces the interparticle repulsion. The sample has the open structure (e.g., cornflake microstructure, Fig. 3). The open structure formed by kaolinite smectite laminar particles that contact either edge-to-edge or edgeto-face (Pyne and Howard 2004). Two composite adsorbents Kaolinite/Smectite-A and Kaolinite/Smectite-B appear (but not necessarily) ultrafine-grained. Ultrafine-grained particles
Table 1 Results of XRD analysis of provided composite clay samples

\begin{tabular}{llllllllll}
\hline Mine name & Quartz & Calcite & Dolomite & Gypsum & Pyrite & Hematite & Apatite & $\begin{array}{l}\text { Fluor } \\
\text { apatite }\end{array}$ & Clay \\
\hline Wasif\% & 7.61 & 85.26 & - & - & - & 2.47 & - & - & 4.67 \\
Bayda\% & 62.76 & 26.09 & - & 3.35 & - & - & - & 2.71 & 5.1 \\
\hline
\end{tabular}

\begin{tabular}{llllllr}
\hline Element name & $\mathrm{Co}$ & $\mathrm{Cr}$ & $\mathrm{Cu}$ & $\mathrm{Ni}$ & $\mathrm{V}$ & $\mathrm{Zn}$ \\
\hline Conc. (ppm) in Wasif & 148 & 68 & 8.5 & 71 & $\mathrm{Nil}$ & 36 \\
Conc. (ppm) in Bayda & 118 & 188 & 58 & 136.7 & 258.4 & 487 \\
\hline
\end{tabular}

Table 2 XRD results for trace elements in composite clay samples
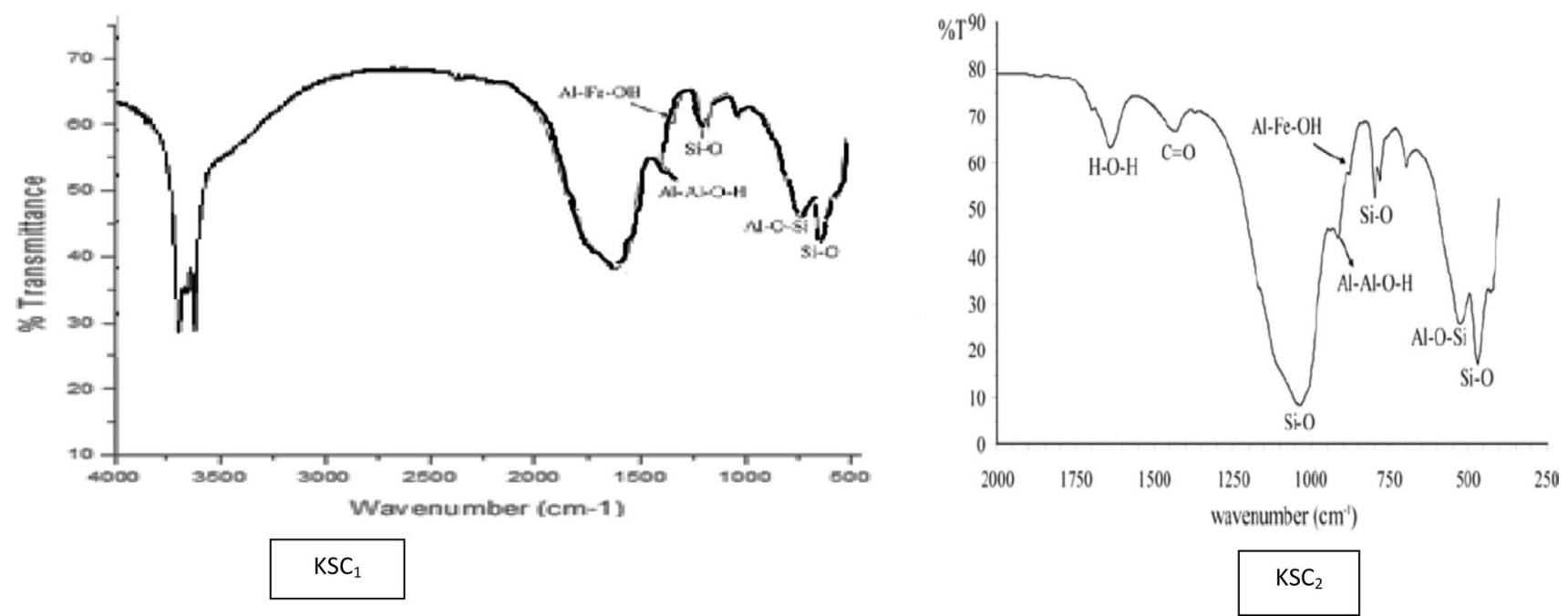

Fig. 2 FTIR spectrum of Kaolinite/Smectite-A and Kaolinite/Smectite-B 
Fig. 3 SEM of Kaolinite/Smectite-A and Kaolinite/Smectite-B

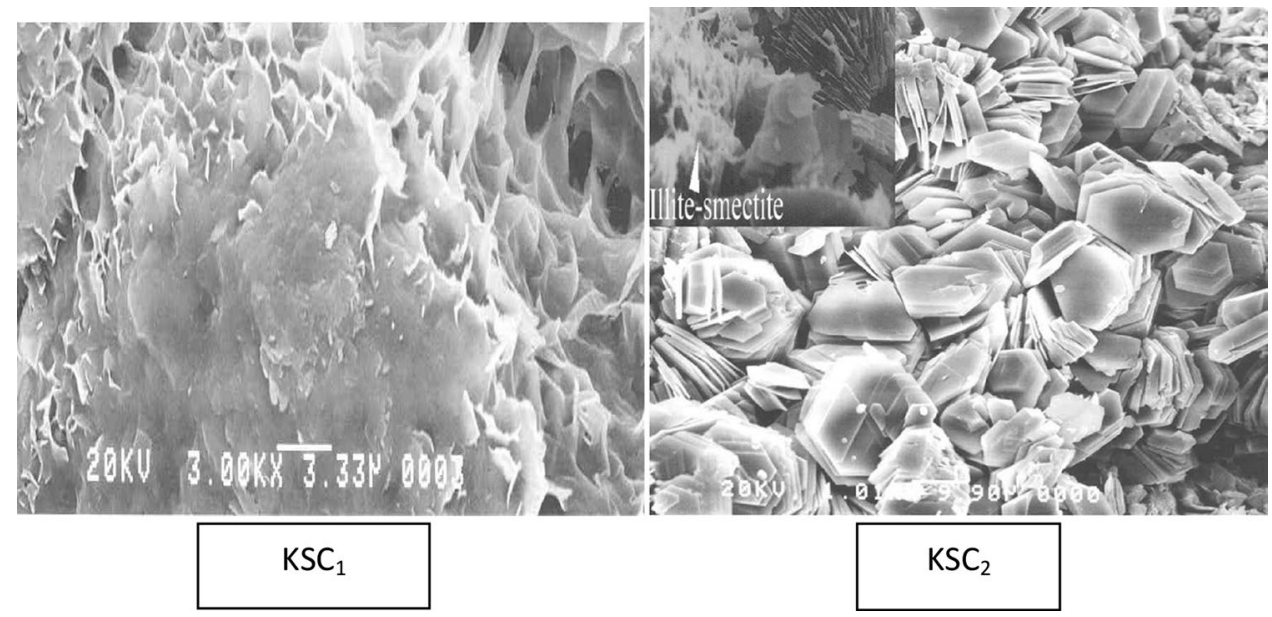

are considered to be $<2 \mu \mathrm{m}$ in size on standard particle size classifications. Usually, the ultrafine grains require special analytical techniques for their identification and study. The kaolinite smectite composite is made of different sizes of clusters. Clusters prevail with spherules particles. Porosity is observed on the clay surface that results in interesting adsorbent properties. In general, it can be observed that total fabrics are completely isotropic. Fabrics are suggested to be formed by random (non-oriented) array of particles.

\section{PH titration}

The results are shown in Fig. 4. Figure 4 shows the $\mathrm{pH}-$ titration curve of two composites Kaolinite/Smectite-A and Kaolinite/Smectite-B. In Fig. 4, the X-axis represents the number of $0.01 \mathrm{M}$ alkali metal hydroxide $(\mathrm{LiOH}, \mathrm{NaOH}$ or $\mathrm{KOH}$ ) millimoles passed through grams of two composites Kaolinite/Smectite-A and Kaolinite/Smectite-B. $Y$-axis shows the $\mathrm{pH}$ value of the effluent passed through the column. The $\mathrm{pH}$ titration curve of two composites Kaolinite/Smectite-A and Kaolinite/Smectite-B under study shows only one inflection point indicating that two composite Kaolinite/Smectite-A andKaolinite/Smectite$\mathrm{B}$ behaves as monofunctional. Furthermore, strong cation exchanger can be identified as indicated by low $\mathrm{pH}(\sim 3)$ of the solution even with no $\mathrm{OH}^{-}$ions added to the system. The rate of $\mathrm{H}^{+}-\mathrm{Na}^{+}$exchange is faster than $\mathrm{H}^{+}-\mathrm{Li}^{+}$and $\mathrm{H}^{+}-\mathrm{K}^{+}$exchanges. The adsorption behavior of alkali metals is observed to be in the order of $\mathrm{Na}(\mathrm{I})>\mathrm{Li}(\mathrm{I})>\mathrm{K}(\mathrm{I})$ in acidic and basic media (Zhu et al. 2016a).

\section{Chemical stability}

It was found that the two composites Kaolinite/Smectite-A and Kaolinite/Smectite-B samples are stable in water and acid solutions up to $6 \mathrm{M} \mathrm{HNO}_{3}$ and $\mathrm{HCl}$, while the samples

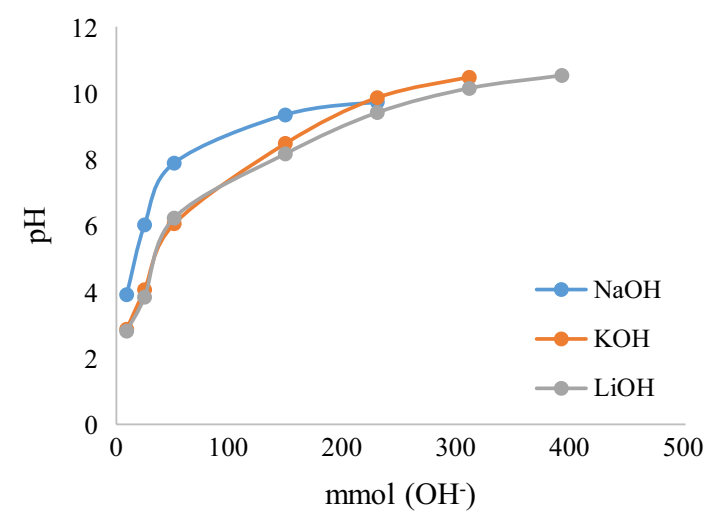

Fig. 4 PH titration curves for the two composite Kaolinite/SmectiteA and Kaolinite/Smectite-B with various alkali metal hydroxides

are completely dissolved in $7 \mathrm{M}$ acids as shown in Table 3. Two composites Kaolinite/Smectite-A and Kaolinite/Smectite-B samples are completely dissolved in $0.1 \mathrm{M}$ and $1 \mathrm{M}$ ( $\mathrm{NaOH}$ and $\mathrm{KOH}$ ) (Zhu et al. 2016b). The chemical stability of the prepared polyaniline silicotitanate is higher than silicotitanate; this proves that the prepared composite overcame the low chemical stability of inorganic (SiTi).

\section{The general procedure of adsorption}

\section{Effect of $\mathrm{pH}$}

The $\mathrm{pH}$ of the aqueous solution has a significant effect on the adsorptive absorption of isomers presumably due to the impact of the $\mathrm{pH}$ at both sites of binding of the surface of the adsorbent and in the presence of hydrogen in solution. The influence of $\mathrm{pH}$ on the adsorption of $\mathrm{Pb}^{2+}$ ions was studied in the $\mathrm{pH}$ range from 1 to 5 . Figure 5 shows that the adsorption of $\mathrm{Pb}^{2+}$ ions increased with increasing $\mathrm{pH}$ from 1 to 3 for two adsorbents Kaolinite/Smectite-A and

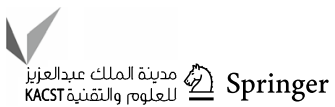


Kaolinite/Smectite-B. At lower $\mathrm{pH}$ values, the concentration of hydrogen ion in the solution increases. $\mathrm{H}^{+}$competes with $\mathrm{Pb}^{2+}$ ions for the binding of the adsorbent, causing the reduction in the adsorption amount of $\mathrm{Pb}^{2+}$ ions. At higher $\mathrm{pH}$ values, the presence of hydrogen ions in the solution decreases. The deprotonated adsorbent surface results in an increase in $\mathrm{Pb}^{2+}$ adsorption. Increasing the $\mathrm{pH}$ causes the precipitation of $\mathrm{Pb}^{2+}$ due to hydroxide formation; therefore at $\mathrm{pH}>5$ was avoided.

\section{Distribution studies}

The potential use of Kaolinite/Smectite-A and Kaolinite/ Smectite-B in separation involving $\mathrm{Pb}^{2+}$ ions was studied. In order to investigate its selectivity for metal ions, distribution coefficient $(\mathrm{Kd})$ was determined at different $\mathrm{pH}$ for each of $\mathrm{Pb}^{2+}$ ions ( $\mathrm{Zhou}$ et al. 2016). The preliminary studies indicate that the time of equilibrium for the exchange of $\mathrm{Pb}^{2+}$ ions with Kaolinite/Smectite-A and Kaolinite/Smectite-B was attained within $24 \mathrm{~h}$. (sufficient to attain equilibrium). The distribution coefficient of the investigated metal ions in demineralized water cannot give us any indications about the selectivity of Kaolinite/Smectite-A and Kaolinite/Smectite$\mathrm{B}$ for any of the cations studied $\left(\mathrm{Pb}^{2+}\right)$. In order to investigate its selectivity for the studied metal cation, the $(\mathrm{Kd})$ was determined at different $\mathrm{pH}$ values. The results of $\mathrm{Kd}$ values are shown in Fig. 6) for Kaolinite/Smectite-A and Kaolinite/ Smectite-B at different conditions.

The linear relationship between $\log \mathrm{Kd}$ and $\mathrm{pH}$ was observed for $\mathrm{Pb}^{2+}$ ions with slopes $(0.682)$ and $\mathrm{Pb}^{+}$, respectively. These slopes were not equal to the valence of the adsorbed metal ions, which provided the non-reality of the exchange reaction. These findings cannot be explained only in terms of the electrostatic interaction between the hydrated cations and the anionic sites in the exchanger. Therefore, it may be considered that the dependence of Kd for cations cannot be understood by a purely columbic interaction with the anionic sites, but may also be due to the formation of a covalent bond similar to a weakly acidic resin, such as the carboxyl. Acid and phosphoric acid, such interaction would be closely related to the ionic potential of the cation (Zhang et al. 2016a).

Figure 7 shows that the Kd values decreased for all the above-mentioned cations with the increase in the drying temperatures of Kaolinite/Smectite-A and Kaolinite/Smectite-B from 50 to $400 \pm 1{ }^{\circ} \mathrm{C}$. This trend may be attributed to the loss of free water and chemical bond water which may act as the exchangeable active site.

In the light of Fig. 8, the Kd values increased for all the above-mentioned cations with the increase in the reaction temperatures of Kaolinite/Smectite-A and Kaolinite/ Smectite-B from 25 to $65 \pm 1{ }^{\circ} \mathrm{C}$, which revealed that all these systems are an endothermic reaction. This trend may

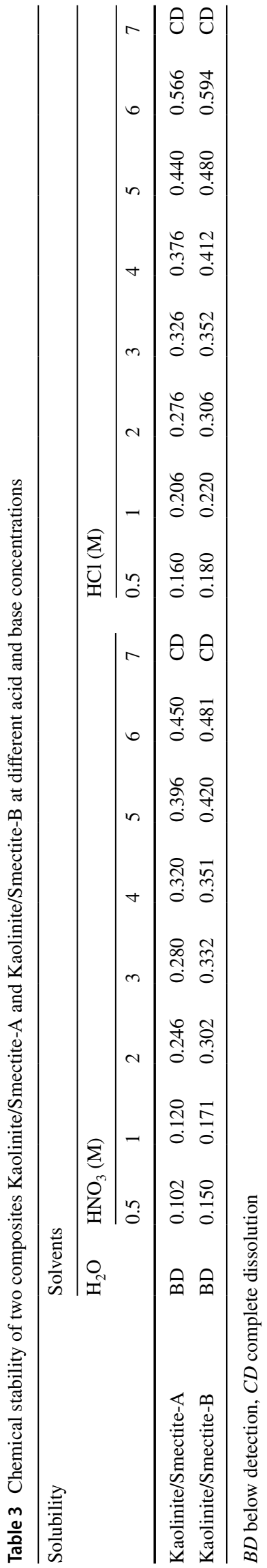




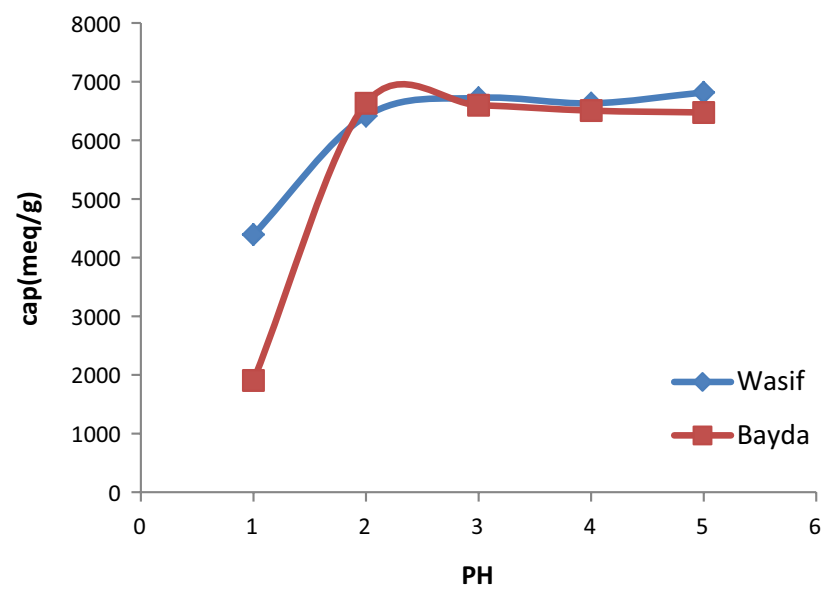

Fig. 5 Effect of $\mathrm{pH}$ on $\mathrm{Pb}^{2+}$ ions adsorption onto Kaolinite/SmectiteA and Kaolinite/Smectite-B

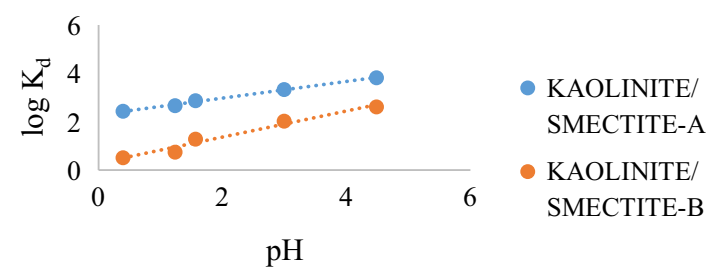

Fig. $6 \log \mathrm{Kd}$ of $\mathrm{Pb}^{2+}$ ions as a function of $\mathrm{pH}$ on Kaolinite/Smectite$\mathrm{A}$ and Kaolinite/Smectite-B at $25 \mathrm{oC}$

be attributed to the mobility of the above-mentioned cations increased with increasing the reaction temperature, so the Kd values increased. These results agree with the data reported (Zhang et al. 2016b), while this result does not agree with the data reported by Fathy et al. (2014b).

It was found that the distribution coefficient of $\mathrm{Pb}^{2+}$ increased with increasing temperature from 298 to $338 \mathrm{~K}$ (i.e., the distribution coefficient decreased with increasing $1 / T)$ as shown in Fig. 9. This increase in the extent of adsorption with the increase in temperature was attributed to the acceleration of some originally slow adsorption steps and creation of some new active sites on the adsorbent surfaces. From the slopes and intercepts of these straight lines represented in Fig. 9, the enthalpy change of adsorption $(\Delta H)$ and entropy change of adsorption $(\Delta S)$ were evaluated and are listed in Table 6 (Zuo et al. 2017).

\section{Apparent capacity measurements}

The ion exchange capacities of Kaolinite/Smectite-A and Kaolinite/Smectite-B samples for $\mathrm{Pb}^{2+}$ ions have been determined as a function of $\mathrm{pH}$ with constant ionic strength (0.1). From Fig. 7 it was found that the capacity of $\mathrm{Pb}^{2+}$ increases by increasing the $\mathrm{pH}$. The increase may be attributed to the

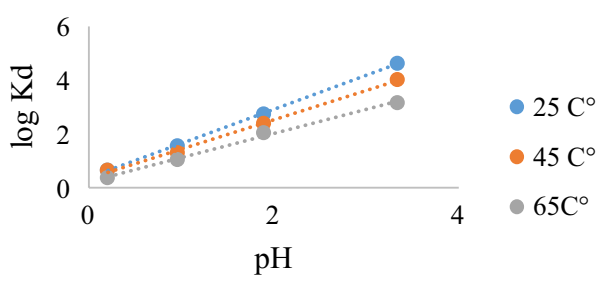

Fig. $7 \log \mathrm{Kd}$ of $\mathrm{Pb}^{2+}$ ion as a function of $\mathrm{pH}$ on Kaolinite/Smectite$\mathrm{A}$ and Kaolinite/Smectite-B at different drying temperatures

decrease of $[\mathrm{H}]^{+}$. The decrease of $[\mathrm{H}]^{+}$in solution facilitates the release of $\mathrm{H}^{+}$from the exchanger in solution leading to an increase of uptake\% values and capacity (Fathy et al. 2015b) (Fig. 10).

\section{Effect of dosage}

The adsorbent dosage is an important parameter for deter-

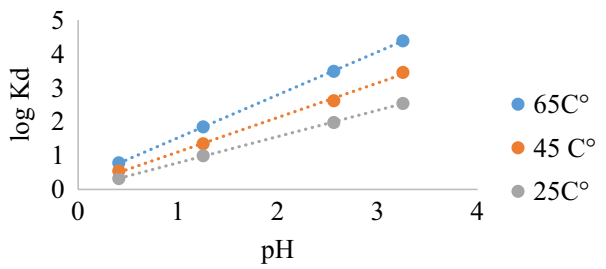

Fig. $8 \log \mathrm{Kd}$ of $\mathrm{Pb}^{2+}$ ion as a function of $\mathrm{pH}$ on Kaolinite/Smectite$\mathrm{A}$ and Kaolinite/Smectite-B at different reaction temperatures

mining the efficiency of an adsorbent for a given initial concentration of adsorbate. The effect of Kaolinite/Smectite$\mathrm{A}$ and Kaolinite/Smectite- $\mathrm{B}$ dosing on $\mathrm{Pb}^{2+}$ removals was studied and is shown in Fig. 11. The dependence of $\mathrm{Pb}^{2+}$ adsorption on the dose was studied by varying the number of adsorbents from 1 to $5 \mathrm{~g}$ maintaining other $\mathrm{pH}$ parameters ( $\mathrm{pH} 3$ in the case of $\mathrm{Pb}^{2+}$ agitation period $(1 \mathrm{~h})$ and constant metal ion concentration $(125 \mathrm{mg} / \mathrm{L})$. The adsorption efficiency in the first step increased with the adsorbent dose increase, and the percentage of removal of $\mathrm{Pb}^{2+}$ with increasing amount of Kaolinite/Smectite-A and Kaolinite/ Smectite-B did not cause any significant changes in adsorption, which may be due to the overlap of adsorption sites as a result of adsorptive particle overlays (Zhang et al. 2016c).

\section{Effect of initial metal ion concentration}

The absorption of $\mathrm{Pb}^{2+}$ in adsorbents Kaolinite/Smectite-A and Kaolinite/Smectite-B is significantly influenced by the initial concentration of the metal ions solutions. Therefore, to study the initial concentration effect, parameters such as adsorbent dose $(1 \mathrm{~g})$, agitation time $(1 \mathrm{~h})$ and $\mathrm{pH}(\mathrm{pH} 3)$ 
are kept constant and the concentration of $\mathrm{Pb}^{2+}$ ion solution varies from The percentage removal was analyzed and there was an increase in the range from 39 to $59 \%$ from 75 to $125 \mathrm{ppm} / \mathrm{L}$ for Wasif $39-79 \%$ from 75 to $125 \mathrm{ppm} / \mathrm{L}$ for Bayda, respectively. Generally, as the metal ion concentration increases, the adsorption tends to decrease due to saturation of the adsorbent as shown in Fig. 12. But in this study, the insignificant decrease was found by increasing the concentration of metal ions. This is due to a higher rate of adsorption and efficiency of the adsorbent through the use of all available active sites for the adsorption process (Yang et al. 2016). Almost all $\mathrm{Pb}^{2+}$ ions were adsorbed very rapidly on the surface of the adsorbent, showing that the adsorbent can be effectively used to remove heavy metal ions, even at very low concentrations, and Bayda, more effective than Wasif.

\section{Effect of contact time}

The experiments were carried out to test the effect of contact time in the adsorption process on Kaolinite/Smectite$\mathrm{A}$ and Kaolinite/Smectite-B adsorbents. The adsorption experiments were carried out between 15 and 120 min at a constant dose of adsorbent $(1 \mathrm{~g})$, concentration of metal ions $(125 \mathrm{mg} / \mathrm{L})$ and $\mathrm{pH} 3.0$. The results indicated that $\mathrm{Pb}^{2+}$ adsorption increases with increasing contact time Fig. 13. The initial rapid elimination rate was observed due to the availability of sufficient vague adsorption sites. Subsequently, the percentage of metal ions removal rate was significantly decreased due to the availability of limited vague premises. The equilibrium adsorption was reached at 45, $30 \mathrm{~min}$ for the adsorbents Kaolinite/Smectite-A and Kaolinite/Smectite-B. An additional increase in the contact time did not increase the uptake due to the deposition of metal ions in the adsorption sites available in the adsorbent materials (Suh et al. 2016).

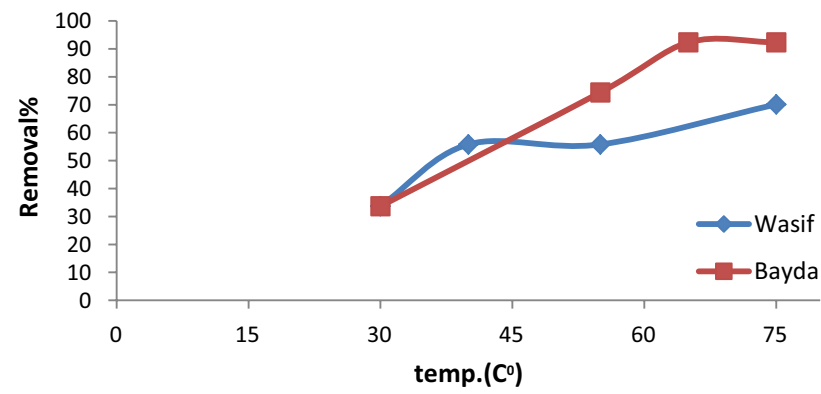

Fig. 9 Effect of temperature on $\mathrm{Pb}^{2+}$ ions adsorption onto oil shell $\mathrm{KSC}_{1}$ and $\mathrm{KSC}_{2}$

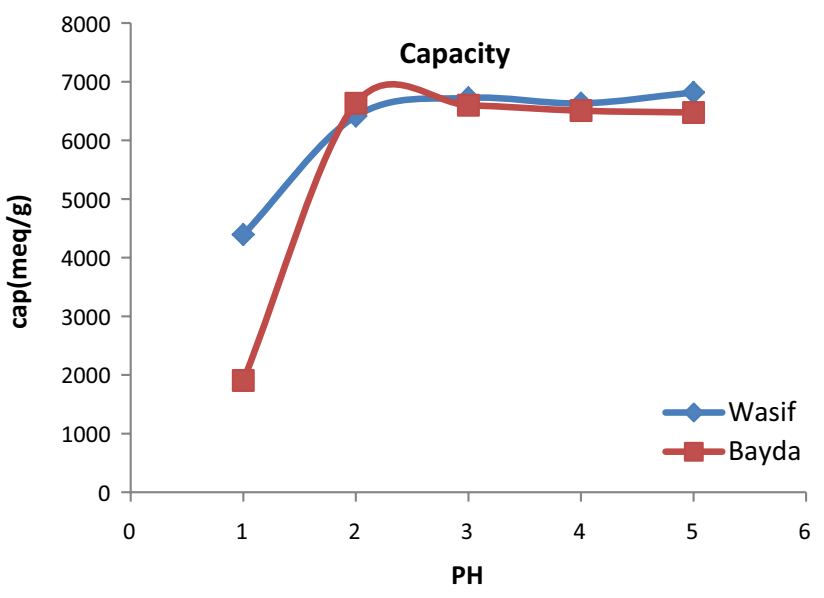

Fig. 10 plots of capacity against $\mathrm{pH}$ for the exchange of $\mathrm{Pb}^{2+}$ on oil shell Kaolinite/Smectite-A and Kaolinite/Smectite-B

\section{Modeling of kinetics}

\section{Pseudo-first-order kinetic model}

The equation of the kinetic model of pseudo-first order was given by Lagergren; its linear form, the most popular form of the equation of the kinetic model of pseudo-first order is given below (Lin et al. 2017):

$\log \left(Q_{\mathrm{e}}-Q_{t}\right)=\log Q_{\mathrm{e}}-K_{1} 2.303 t$

where $K_{1}$ is a constant rate of pseudo-first order of the equation $\left(\mathrm{min}^{-1}\right)$, and $Q_{\mathrm{e}}$ and $Q_{t}(\mathrm{mmol} / \mathrm{g})$ are the amounts of non-equilibrium adsorbed $\mathrm{Pb}^{2+}$, not time, respectively. $\left(Q_{1}\right.$ and $Q_{\mathrm{e}}$ cal) can be calculated from the slope and intersection of a $\log$ graph $\left(Q_{\mathrm{e}}-Q_{t}\right)$ versus $t$. At a constant rate of adsorption of the pseudo-first order $K_{1}$, an equilibrium adsorption capacity $\left(Q_{\mathrm{e}-\text { lime }}\right)$ and amount of equilibrium adsorption $\left(Q_{\mathrm{e} \text {-exp }}\right)$ two experiments or correlation coefficient

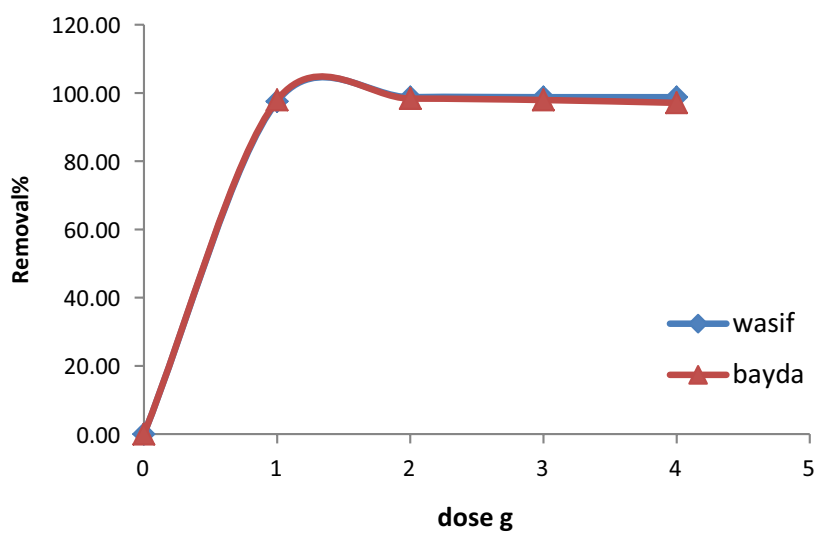

Fig. 11 Effect of dosage on $\mathrm{Pb}^{2+}$ ions adsorption onto oil shell Kaolinite/Smectite-A and Kaolinite/Smectite-B 
(R2) are listed in Table 4 and Fig. 14. Table 4 shows that a theoretical equilibrium adsorption quantity $\left(Q_{\text {e-cal }}\right)$, calculated from the kinetic model of the pseudo-first order, does not agree with the experimental values $\left(Q_{\text {e-exp }}\right)$.

\section{Pseudo-second-order kinetic model}

The pseudo-second equation model assumes that the limiting step is the chemical adsorption or the chemical adsorption step involving the valence forces of the shared electrons or exchanged between the adsorbent and the adsorbed. This kinetic model has been widely used to describe trace elements and adsorption of organic compounds in two adsorbents Kaolinite/Smectite-A and Kaolinite/Smectite-B and is used to describe the adsorption kinetics of ions in adsorbent materials. The integrated and linearized form of the equation is given as (Duan et al. 2016):

$\frac{t}{q_{t}}=\frac{1}{K 2 q_{e^{2}}}+\frac{1}{q_{\mathrm{e}}} t$

where $k_{2}$ (in grams per milligram per minute) is the pseudosecond-order constant adsorption rate. If a pseudo-second-order kinetics is applicable, the graph of t/qt versus $t$ (Fig. 15) the two adsorbents Kaolinite/Smectite-A and Kaolinite/Smectite-B used will give straight lines $q_{\mathrm{e}}$ and $k_{2}$ (Table 4) which can be determined from the slope and intersection of the plot, respectively.

\section{Theory of adsorption}

\section{Adsorption isotherms}

The adsorption equilibrium is typically described by an isothermal equation whose parameters articulate the surface properties and affinity of the adsorbent. The adsorption

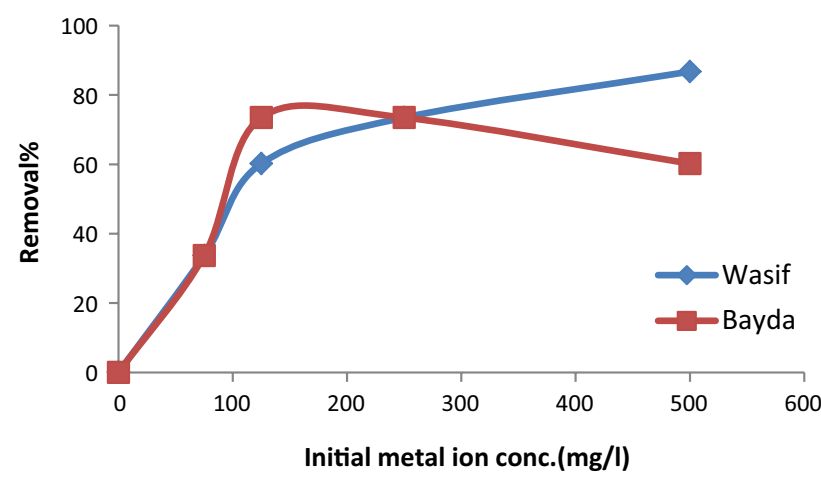

Fig. 12 The effect of initial metal ion concentration on $\mathrm{Pb}^{2+}$ ions adsorption onto oil shell Kaolinite/Smectite-A and Kaolinite/Smectite-B

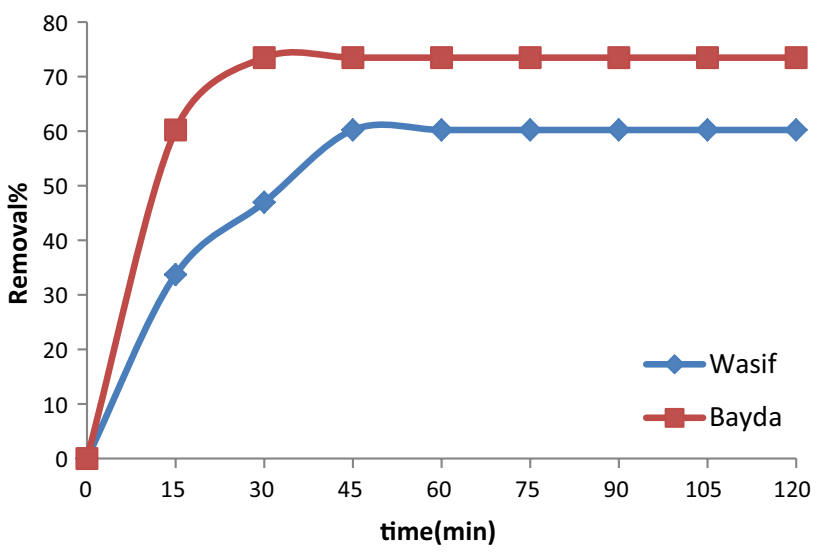

Fig. 13 Effect of contact time on $\mathrm{Pb}^{2+}$ ions adsorption onto oil shell Kaolinite/Smectite-A and Kaolinite/Smectite-B

isotherms can be generated based on many theoretical models where the Langmuir and Freundlich models are the most used. The Langmuir model assumes that the absorption of metallic ions occurs on a homogeneous surface by monolayer adsorption, without any interaction between the adsorbed ions. The model assumes the following form:

$\frac{C_{\mathrm{e}}}{q_{\mathrm{e}}}=\frac{1}{b Q_{0}}+\frac{C_{\mathrm{e}}}{Q_{0}}$

here $C_{\mathrm{e}}$ is the equilibrium concentration of adsorbate $(\mathrm{mg} / \mathrm{L})$, $Q_{\mathrm{e}}$ is the adsorbed amount $(\mathrm{mg} / \mathrm{g})$, and $Q_{0}(\mathrm{mg} / \mathrm{g})$ and $b(\mathrm{~L} /$ $\mathrm{mg}$ ) are the Langmuir constants. The Freundlich equation is an empirical equation based on adsorption on a heterogeneous surface. The equation is commonly represented by:

$\log Q_{\mathrm{e}}=\log K_{\mathrm{f}}+\frac{1}{n} \log C_{\mathrm{e}}$

where $Q_{\mathrm{e}}$ is the adsorbed amount $(\mathrm{mg} / \mathrm{g}), C_{\mathrm{e}}$ is the equilibrium concentration of adsorbate $(\mathrm{mg} / \mathrm{L})$, and $K_{\mathrm{f}}$ $\left(\mathrm{mg} \mathrm{L}^{-1} / \mathrm{n} \mathrm{L}^{-1} / \mathrm{ng}^{-1}\right)$ en $(\mathrm{g} / \mathrm{L})$ are the characteristics of Freundlich System constants, which indicate the adsorption capacity and the adsorption intensity, respectively.

The relative values of $Q_{\mathrm{m}}, b, K_{\mathrm{f}}$ and $n$ obtained as calculated from Langmuir and Freundlich models of $\mathrm{Pb}^{2+}$ on both Wasif and Bayda clay are listed in Table 5. The results showed that experimental data are well fitted to the Freundlich isotherm. As shown in Table 5, when Langmuir model

Table 4 Pseudo-first and second-order parameters

\begin{tabular}{llllll}
\hline Item & Wasif & & & Bayda \\
\cline { 2 - 3 } & 1st order & 2nd order & & 1st order & 2nd order \\
\hline$R^{2}$ & 1 & 1 & 1 & 1 \\
$K_{1}$ & 0.098 & 0.004460067 & & 0.0801 & 0.004149818 \\
cal. $q_{\mathrm{e}}$ & 1.661 & 0.10609967 & & 0.2371 & 0.105799953 \\
Exp. $q_{\mathrm{e}}$ & -4.868 & 0.1061 & & 4.801 & 0.1058 \\
\hline
\end{tabular}




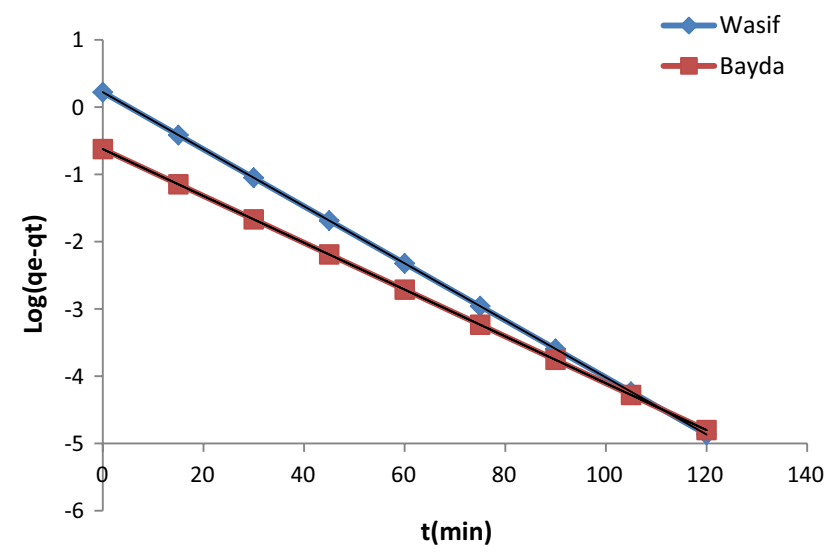

Fig. 14 Plotting of pseudo-first order model for Kaolinite/Smectite-A and Kaolinite/Smectite-B

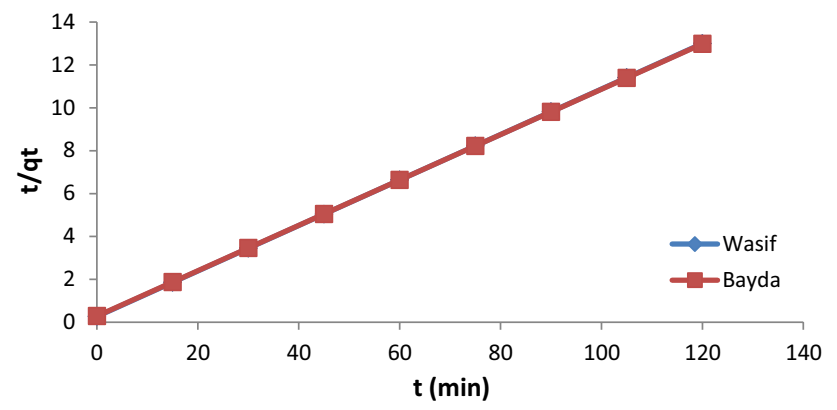

Fig. 15 Plotting of pseudo-second-order model for Kaolinite/Smectite-A and Kaolinite/Smectite-B

was used to describe the adsorption of $\mathrm{Pb}^{2+}$ onto Wasif and Bayda clay, the linear plot of $C_{\mathrm{e}} / Q_{\mathrm{e}}$ versus $C_{\mathrm{e}}$ with regression coefficients $R^{2}=0.74$ and 0.86 was obtained, and the maximum adsorption capacity of Wasif and Bayda clay for $\mathrm{Pb}^{2+}$ was calculated to be 5.84 and $6.51 \mathrm{mg} / \mathrm{g}$, respectively. Simultaneously, the linear plot of $\operatorname{logged}$ versus $\log C_{\mathrm{e}}$ with regression coefficients $R^{2}=1$ and 0.99 was obtained, and the Freundlich constant $K_{\mathrm{f}}$ of Wasif and Bayda clay for $\mathrm{Pb}^{2+}$ was calculated to be $1.17 \mathrm{E}-03$ and 2.53 , respectively. In each case, the value of $n$ was $>1$, indicating that adsorption $n$ was favorable. And similar results were observed in previous studies on the adsorption of heavy metal ions attached to the isothermal Langmuir. On the basis of these results, it was concluded that the adsorption coefficients are in good agreement with each other to promote proper adsorption. The friendly ability is great, in keeping with its ability to take more metal ions. Both Langmuir and Freundlich suggested that the modified kaolin had much better absorption.

\section{Effect of temperature}

The extent of $\mathrm{Pb}^{2+}$ adsorption on the oil shell Kaolinite/ Smectite-A and Kaolinite/Smectite-B at various temperatures is shown in Fig. 16. As observed from the figures, temperature raises results in an increase in the removal a percentage of the metals ions. The enhancement of the adsorption capacity when the temperature is increased is due to increased mobility and diffusion of the ionic species. The adsorption experiment could be regarded as a heterogeneous and reversible process at equilibrium. The apparent equilibrium constant for the process is shown to be (Brudey et al. 2016):

$K_{C}=\left(C_{0}-C_{\mathrm{e}}\right) / C_{\mathrm{e}}$

The Gibbs free energy of the adsorption process is:

$\Delta G=-R T \ln K_{c}$

where $\Delta G$ is the Gibbs free energy change for the adsorption process $\left(\mathrm{J} \mathrm{mol}^{-1}\right) ; R$ the universal gas constant (8.314 $\mathrm{J} \mathrm{mol}^{-1} \mathrm{~K}^{-1}$ ), while $T$ is the temperature $(\mathrm{K})$. The effect of temperature on the adsorption of $\mathrm{Pb}^{2+}$ by oil shell Kaolinite/Smectite-A and Kaolinite/Smectite-B is listed in Table 6.

\section{Thermodynamics of $\mathrm{Pb}$ (II) adsorption}

\section{Thermodynamics of adsorption}

Thermodynamic parameters can be determined using a constant equilibrium, $K_{d}\left(Q_{\mathrm{e}} / C_{\mathrm{e}}\right)$, which depends on the temperature. The entropy $(\Delta S)$ and entropy $(\Delta H)$ associated with the adsorption process were calculated using the following equations (Anastopoulos et al. 2016; Sevim et al. 2016):

$\operatorname{Ln} K_{d}=\Delta S / R-(R \Delta H / R T)$

where $T(\mathrm{~K})$ is the temperature and $R(8.3145 \mathrm{~J} / \mathrm{mol} \mathrm{K})$ is the ideal gas constant. The Gibbs free energy, $\Delta G$, of specific adsorption is calculated from the equation:

$\Delta G=\Delta H-T \Delta S$

According to Eqs. (8) and (9), $\Delta H, \Delta S$, and $\Delta G$ parameters can be calculated.

The plots of $\ln K_{d}$ against $1 / T$ are shown in Fig. 17. The values of $\Delta \mathrm{H}$ and $\Delta S$ of $\mathrm{Pb}$ (II) adsorption were calculated by fitting the experimental data to Eq. (8) as shown in Fig. 14. $\Delta G$ values were obtained by using Eq. (9). The thermodynamic parameters for the adsorption of $\mathrm{Pb}$ (II) are given in Table 6 . The negative value of enthalpy change, $\Delta \mathrm{H}, 1.50 \mathrm{E}-02$ and $2.18 \mathrm{E}+07 \mathrm{~kJ} / \mathrm{mol}$ for Wasif and Bayda clay adsorbents, respectively, indicated that the adsorption of $\mathrm{Pb}^{2+}$ on both adsorbents was an endothermic process with adsorption onto unmodified adsorbent being more exothermic. The value of $\Delta S$, for Wasif and Bayda clay, was $2.83 \mathrm{E}-02 \mathrm{~J} / \mathrm{molK}$ and $79 \mathrm{~J} / \mathrm{mol} \mathrm{K}^{-1}$, 
Table 5 Langmuir and Freundlich isotherms parameters for the adsorption of $\mathrm{Pb}^{2+}$ ions adsorption onto Kaolinite/Smectite-A and Kaolinite/Smectite-B

\begin{tabular}{|c|c|c|c|c|c|c|c|}
\hline \multirow[t]{2}{*}{ Cation } & \multirow{2}{*}{$\begin{array}{l}\text { Reaction tem- } \\
\text { perature }(\mathrm{K})\end{array}$} & \multicolumn{3}{|c|}{ Freundlich isotherm } & \multicolumn{3}{|c|}{ Langmuir isotherm } \\
\hline & & $K_{\mathrm{f}}$ & $n$ & $R^{2}$ & $Q_{\mathrm{m}}$ & $b$ & $R^{2}$ \\
\hline \multirow[t]{5}{*}{ Wasif } & 303 & $6.0605 \mathrm{E}-07$ & $2.52 \mathrm{E}-01$ & 0.99 & 0.78 & $8.74 \mathrm{E}-03$ & 0.83 \\
\hline & 313 & $3.79 \mathrm{E}-03$ & $5.72 \mathrm{E}-01$ & 1.00 & 517.29 & 29.26 & 0.78 \\
\hline & 328 & $2.47 \mathrm{E}-03$ & $5.43 \mathrm{E}-01$ & 0.99 & 1.65 & $1.62 \mathrm{E}-01$ & 0.84 \\
\hline & 338 & $2.46 \mathrm{E}-04$ & $4.82 \mathrm{E}-01$ & 0.99 & 3.94 & $6.25 \mathrm{E}-02$ & 0.98 \\
\hline & 348 & $1.17 \mathrm{E}-03$ & $3.69 \mathrm{E}-01$ & 1.00 & 2.12 & $5.10 \mathrm{E}-01$ & 0.74 \\
\hline \multirow[t]{5}{*}{ Bayda } & 303 & 0.11 & 0.94 & 1.00 & 25.81 & 4.81 & 0.96 \\
\hline & 313 & 0.48 & 0.89 & 0.98 & 60.95 & 46.89 & 0.69 \\
\hline & 328 & $9.2077 \mathrm{E}-05$ & 0.21 & 0.98 & 1.50 & 0.27 & 0.80 \\
\hline & 338 & 0.56 & 1.04 & 0.98 & 205.54 & 104.06 & 0.99 \\
\hline & 348 & 2.53 & 1.60 & 0.99 & 40.58 & 62.85587 & 0.86 \\
\hline
\end{tabular}

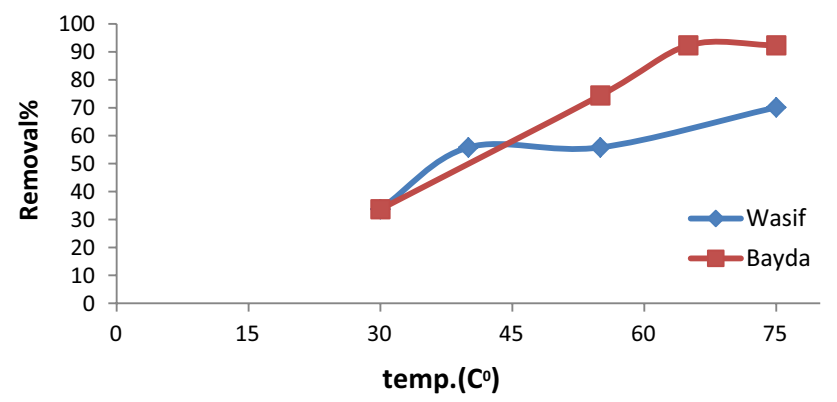

Fig. 16 Effect of temperature on $\mathrm{Pb}^{2+}$ ions adsorption onto oil shell Kaolinite/Smectite-A and Kaolinite/Smectite-B

respectively. It indicated that $\mathrm{Pb}(\mathrm{II})$ in bulk phase (aqueous solution) was in a much more chaotic distribution compared to the relatively ordered state of a solid phase (surface adsorbent). The Gibbs free energy $\Delta G^{\circ}$, listed in Table 6, as calculated for adsorption of $\mathrm{Pb}$ (II) Wasif and Bayda clay was $-185,-345$, $-584,-744,-904 \mathrm{~kJ} / \mathrm{mol}$ and $-3540,-4800,-6700$, $-7960,-9230 \mathrm{~kJ} / \mathrm{mol}$, respectively, when the temperature was set at $303,313,328,338$, and $348 \mathrm{~K}$.

This suggests that adsorption of $\mathrm{Pb}$ (II) on the modified adsorbent was possible and thermodynamic thermal. However, the positive change in $\Delta \mathrm{G}$ indicates that the adsorption forces were not strong enough to break the potential and eventually the right-handed interaction. (II) on the surface components of the unmodified adsorbent. In addition, the amount of $\mathrm{Pb}$ (II) adsorbed at five different temperatures showed a high-temperature rise accompanied by a decrease in entropy, and the Gibbs energy increased to adsorption of $\mathrm{Pb}(\mathrm{II})$ on Wasif and Bayda clay was favorable at higher temperatures (Sankararamakrishnan et al. 2016).

\section{Conclusion}

The results showed that the oil shell rock can be used to remove metal ions such as $\mathrm{Pb}$ (II) from the aqueous solution in metal ions. The adsorption capacity of $\mathrm{Pb}$ (II) in the clay of the caulinite is greater than other ions tested. There are several factors that affect the adsorption of metal ions in the caulinite clay; however, the $\mathrm{pH}$ is a significant impact on the adsorption of metal ions in the clay of the caulinite. In addition, the experimental data were better adjusted with the Freundlich equation than the Langmuir model. This indicated that, although the interactions were predominantly chemical, the adsorption sites were not uniform and non-specific in nature. In addition, the characterization of the caulinite clays showed the low surface
Table 6 Thermodynamics parameters of $\mathrm{Pb}^{2+}$ ions adsorption onto Kaolinite/ Smectite-A and Kaolinite/ Smectite-B

\begin{tabular}{llllllll}
\hline Adsorbent & $T$ & $1 / T$ & $K_{c}$ & $\operatorname{Ln} K_{c}$ & $\Delta G$ & $\Delta H$ & $\Delta S$ \\
\hline Wasif & 303 & $3.30 \mathrm{E}-03$ & 0.27 & 0.07 & $-1.85 \mathrm{E}+02$ & $1.50 \mathrm{E}-02$ & $2.83 \mathrm{E}-02$ \\
& 313 & $3.19 \mathrm{E}-03$ & 0.48 & 0.13 & $-3.45 \mathrm{E}+02$ & $1.50 \mathrm{E}-02$ & $2.83 \mathrm{E}-02$ \\
& 328 & $3.05 \mathrm{E}-03$ & 0.78 & 0.21 & $-5.84 \mathrm{E}+02$ & $1.50 \mathrm{E}-02$ & $2.83 \mathrm{E}-02$ \\
& 338 & $2.96 \mathrm{E}-03$ & 0.97 & 0.26 & $-7.44 \mathrm{E}+02$ & $1.50 \mathrm{E}-02$ & $2.83 \mathrm{E}-02$ \\
& 348 & $2.87 \mathrm{E}-03$ & 1.14 & 0.31 & $-9.04 \mathrm{E}+02$ & $1.50 \mathrm{E}-02$ & $2.83 \mathrm{E}-02$ \\
Bayda & 303 & $3.30 \mathrm{E}-03$ & 5.13 & 1.40 & $-3.54 \mathrm{E}+03$ & $2.18 \mathrm{E}+07$ & $7.90 \mathrm{E}+01$ \\
& 313 & $3.19 \mathrm{E}-03$ & 6.74 & 1.85 & $-4.80 \mathrm{E}+03$ & $2.18 \mathrm{E}+07$ & $7.90 \mathrm{E}+01$ \\
& 328 & $3.05 \mathrm{E}-03$ & 8.97 & 2.46 & $-6.70 \mathrm{E}+03$ & $2.18 \mathrm{E}+07$ & $7.90 \mathrm{E}+01$ \\
& 338 & $2.96 \mathrm{E}-03$ & 10.35 & 2.83 & $-7.96 \mathrm{E}+03$ & $2.18 \mathrm{E}+07$ & $7.90 \mathrm{E}+01$ \\
& 348 & $2.87 \mathrm{E}-03$ & 11.65 & 3.19 & $-9.23 \mathrm{E}+03$ & $2.18 \mathrm{E}+07$ & $7.90 \mathrm{E}+01$ \\
\hline
\end{tabular}




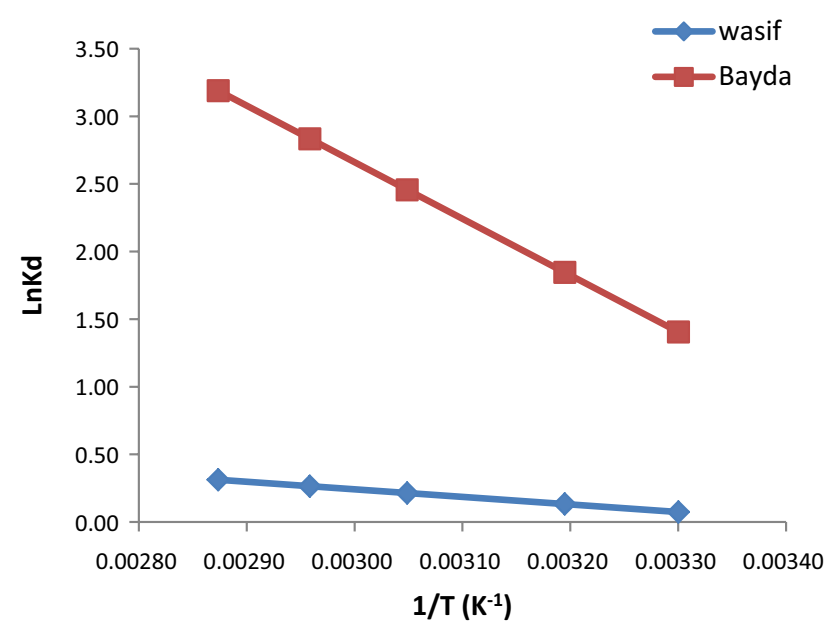

Fig. 17 Effect of temperature on $\mathrm{Pb}^{2+}$ ions adsorption onto oil shell Kaolinite/Smectite-A and Kaolinite/Smectite-B

area of a low percentage of caulinite components in the clay. He also proved that caulinite clay can be used for the removal of heavy metals in real wastewater.

1. The compound adsorbent revealed efficiency in the removal of aqueous solutions of $\mathrm{Ca}^{2+}, \mathrm{Fe}^{3+}$ and $\mathrm{Mg}^{2+}$.

2. The removal efficiency depended on the $\mathrm{pH}$, initial concentration of ions and contact time of the solution, where the equilibrium time was $15 \mathrm{~min}$ and adsorbent concentration of about $1 \mathrm{~g}$ for the two ions studied.

3. The study of the thermodynamic variables showed that the adsorption was thermodynamically spontaneous and endothermic in usual circumstances.

4. The equilibrium data adjusted the Freundlich isotherm, indicating heterogeneity in the sorption sites and the adsorption process is the physical adsorption.

Open Access This article is distributed under the terms of the Creative Commons Attribution 4.0 International License (http://creativeco mmons.org/licenses/by/4.0/), which permits unrestricted use, distribution, and reproduction in any medium, provided you give appropriate credit to the original author(s) and the source, provide a link to the Creative Commons license, and indicate if changes were made.

\section{References}

Anastopoulos I, Bhatnagar A, Lima EC (2016) Adsorption of rare earth metals: a review of recent literature. J Mol Liq 221:954-962

Brudey $\mathrm{T}$ et al (2016) Adsorption of lead by chemically activated carbons from three lignocellulosic precursors. J Anal Appl Pyrolysis 120:450-463

Duan S et al (2016) Highly efficient entrapment of U(VI) by using porous magnetic Ni0.6Fe2.4O4 micro-particles as the adsorbent. J Taiwan Inst Chem Eng 65:367-377
El-Maghrabi H, Hosny R, Ramzi M, Fathy M (2017) Novel mesoporous silica (MCM-41) and its characterization for oil adsorption from produced water injected in water injection projects using fixed bed column processes. Desalin Water Treat 60:70-77

Farrag AEHA, Moghny TA, Mohamed AMG, Saleem SS, Fathy M (2016a) Abu Zenima synthetic zeolite for removing iron and manganese from Assiut governorate groundwater, Egypt. Appl Water Sci 7:3087-3094. https://doi.org/10.1007/s13201-016-0435-y

Farrag AEHA, Moghny TA, Gad AM, Saleem SS, Fathy M, Ahmed MA (2016b) Removing of hardness salts from groundwater by thermogenic synthesis zeolite. SDRP J Earth Sci Environ Stud $1: 109-119$

Fathy M et al (2014a) Study the adsorption of sulfates by high crosslinked polystyrene divinylbenzene anion-exchange resin. Appl Water Sci 7:1-5

Fathy M et al (2014b) Incorporation of multi-walled carbon nanotubes in microspheres used as anion exchange resin via suspension polymerization. Appl Nanosci 4(5):543-549

Fathy M, Moghny TA, Awadallah AE, Abdou MM, El-Bellihi AHAA (2015a) Development of sulfonated nanocomposites ion exchange resin for removal of sodium ions from saline water. Int J Modern Organ Chem 4(1):62-69

Fathy M, Moghny TA, Awadallah AE, El-Bellihi AHAA (2015b) Study the adsorption of $\mathrm{Ca}$ (II) and $\mathrm{Mg}$ (II) on high crosslinked polystyrene divinyl benzene resin. Int J Modern Chem 7(1):36-44

Fathy M, Moghny TA, Mousa MA, El-Bellihi AHAA, Awadallah AE (2016a) Absorption of calcium ions on oxidized graphene sheets and study its dynamic behavior by kinetic and isothermal models. Appl Nanosci 6:1105-1117. https://doi.org/10.1007/s1320 4-016-0537-8

Fathy M, Moghny TA, Mousa MA, El-Bellihi AH, Awadallah AE (2016b) Synthesis of transparent amorphous carbon thin films from cellulose powder in rice straw. Arab J Sci Eng 42:225-233. https://doi.org/10.1007/s13369-016-2273-5

Fernandez-Álvarez G et al (2010) Autopsy of SWRO membranes from desalination plant in Ceuta after 8 years in operation. Desalination 263(1-3):264-270

Karime M, Bouguecha S, Hamrouni B (2008) RO membrane autopsy of Zarzis brackish water desalination plant. Desalination 220(1-3):258-266

Lin L, Wang H, Xu P (2017) Immobilized $\mathrm{TiO}_{2}$-reduced graphene oxide nanocomposites on optical fibers as high performance photocatalysts for degradation of pharmaceuticals. Chem Eng $\mathbf{J}$ 310:389-398

Pyne RDG, Howard JB (2004) Desalination/Aquifer Storage Recovery (DASR): a cost-effective combination for Corpus Christi, Texas. Desalination 165:363-367

Sankararamakrishnan N, Chauhan D, Dwivedi J (2016) Synthesis of functionalized carbon nanotubes by floating catalytic chemical vapor deposition method and their sorption behavior toward arsenic. Chem Eng J 284:599-608

Sevim M et al (2016) Bimetallic MPt (M: co, Cu, Ni) alloy nanoparticles assembled on reduced graphene oxide as high performance cathode catalysts for rechargable lithium-oxygen batteries. J Alloys Compd 683:231-240

Suh W et al (2016) Graphene supported Pt-Ni nanoparticles for oxygen reduction reaction in acidic electrolyte. Int J Hydrogen Energy 41:12983-12994

Yang Y et al (2016) $\mathrm{TiO}_{2}$ /graphene porous composite and its photocatalytic degradation of methylene blue. Mater Des 108:632-639

Zhang Z et al (2016a) One-step fabrication of electrochemical biosensor based on DNA-modified three-dimensional reduced graphene oxide and chitosan nanocomposite for highly sensitive detection of $\mathrm{Hg}$ (II). Sens Actuators B Chem 225:453-462 
Zhang Y et al (2016b) Facile synthesis of Pt nanoparticles loaded porous graphene towards oxygen reduction reaction. Mater Des 96:323-328

Zhang J et al (2016c) Fluorescent nanoprobes for sensing and imaging of metal ions: recent advances and future perspectives. Nano Today 11:309-329

Zhou Z et al (2016) Solvothermal synthesis of Na2Ti3O7 nanowires embedded in 3D graphene networks as an anode for high-performance sodium-ion batteries. Electrochim Acta 211:430-436
Zhu Y et al (2016a) Kinetics and thermodynamics of Eu(III) adsorption onto synthetic monoclinic pyrrhotite. J Mol Liq 218:565-570

Zhu Y et al (2016b) Kinetics and thermodynamics of Eu(III) and U(VI) adsorption onto palygorskite. J Mol Liq 219:272-278

Zuo L-X, Jiang L-P, Zhu J-J (2017) A facile sonochemical route for the synthesis of MoS2/Pd composites for highly efficient oxygen reduction reaction. Ultrasonics Sonochem 35:681-688 